\title{
Global dimensions of chronic kidney disease of unknown etiology (CKDu): a modern era environmental and/or occupational nephropathy?
}

\author{
Virginia M. Weaver ${ }^{1,2,3^{*}}$, Jeffrey J. Fadrowski ${ }^{3,4,5}$ and Bernard G. Jaar ${ }^{2,3,5}$
}

Diabetes and hypertension are the predominant risk factors for chronic kidney disease (CKD) globally. Infectious diseases resulting in glomerulonephritis are also important in low-income countries [1, 2]. However, in the past two decades, a severe form of CKD has been reported in individuals without these risk factors. CKD of unknown etiology (CKDu) affects adults in their third to fifth decade and is often fatal due to disease progression and lack of dialysis or transplant options in the involved geographic areas. CKDu has been reported in Sri Lanka, several Central American countries, the state of Andhra Prakesh in India and the El-Minia Governorate in Egypt.

The results of a joint Sri Lankan and World Health Organization (WHO) funded study focused on identification of risk factors for CKDu in Sri Lanka was recently published in this journal [3]. Subsequent correspondence, highlighting the range of risk factors under consideration, illustrates the complexity of this endeavor $[4,5]$. Despite the comprehensive exposure assessment of Jayatilake and colleagues, and prior work in Sri Lanka and Central America, the name CKDu remains appropriate because the etiology is still unknown. Consideration of the similarities and differences in CKDu in the four regions in which it has been reported to date may be useful in the effort to determine causality and develop prevention strategies. Therefore, the table included in this manuscript compares and contrasts the currently available information on CKDu. Importantly, there is no global definition for this disease. Furthermore, levels of

\footnotetext{
* Correspondence: vweaver1@jhu.edu

'Department of Environmental Health Sciences, Johns Hopkins University Bloomberg School of Public Health, Baltimore, MD, USA

2Department of Medicine, Johns Hopkins Medical Institutions, Baltimore, MD, USA

Full list of author information is available at the end of the article
}

proteinuria and albuminuria tend to be low in Central America [6], however the case definition in Sri Lanka was based on persistent albuminuria defined as an albumin-creatinine ratio $\geq 30 \mathrm{mg} / \mathrm{g}$ in an initial urine sample and at a repeat visit [3]. Therefore, the data below utilize the criteria for CKDu of the authors in each publication.

Given the limited information about CKDu in the affected areas, particularly in Andhra Pradesh and Egypt, it is not clear that the etiology of the kidney disease is the same in all locations. Different risk factors have been emphasized; altitude and occupational risks factors have received more attention in Central America whereas extensive chemical monitoring was recently reported in Sri Lanka [3]. Moreover, case ascertainment in Sri Lanka has relied much more on proteinuria whereas, in Central America, both urine dipstick and serum creatinine have been used in case identification. Data on magnitude remains extremely limited.

However, as shown in the table, a number of similarities are present. The disease is characterized by substantial morbidity and mortality, resulting in death in young and middle aged adult patients, and absence of known causes of CKD such as diabetes and hypertension (or at least severe hypertension as the blood pressure inclusion criteria in the Sri Lankan study was less than 160/100 [3]). Men seem to be more at risk, at least for the most severe disease, and very poor rural areas are most affected with agricultural work being the dominant occupation. Poverty with lack of access to health care makes determining clinical characteristics of CKDu difficult. Even determining when the outbreaks actually started is challenging; $\mathrm{CKDu}$ may have been present for a significant period of time but not identified due to absence of diagnostic testing. Furthermore, many of these areas have recently seen a transition from earlier deaths from infectious diseases to deaths from non-communicable 
diseases in the setting of longer life spans which provides time for CKD to develop and progress.

Few studies have reported on urinary findings in CKDu patients. However, in described clinical presentations, typical patients present with a bland urine sediment and minimal proteinuria (Table 1). Recent studies have measured levels of kidney early biological effect markers in urine $[7,8]$. The results are consistent with proximal tubular damage and may be useful in future work to identify $\mathrm{CKDu}$ at earlier stages and to determine etiology. Information on renal pathology has also been very limited to date. The two studies reporting biopsy results from patients with CKDu in El Salvador both found interstitial fibrosis with varying degrees of tubular atrophy, essentially proportional to stage of CKD. Both series also reported non-specific glomerular damage. Whether this is secondary to a primary tubulointerstitial process or represents a primary glomerular disease or could be due to recurrent ischemia of the glomerular capillaries, such as from dehydration or concomitant use of nonsteroidal antiinflammatory drugs (NSAIDs), remains unknown. Wijkström et al. concluded that the biopsy results from Central America did not resemble any other common kidney disease [9]. Importantly, these findings are similar to those described in CKDu from Sri Lanka [10-12]. It would be very useful to have additional information on pathology, including at earlier stages of the disease process.

\section{Etiologic factors involved in past CKD outbreaks or poisoning due to nephrotoxicants}

A review of investigations to determine etiologic factors involved in past end-stage renal disease (ESRD) outbreaks may also prove informative. Consider, for example, that the cause of Balkan endemic nephropathy remained a mystery for 50 years until the occurrence of nephropathy in individuals ingesting herbal preparations for weight loss led to the identification of aristolochic acid as the cause of both diseases [13]. Chronic interstitial nephritis is the most common pathologic diagnosis in CKD attributed to occupational and/or environmental exposures. It has been reported following excessive exposure to lead, cadmium, and aristolochic acid. Pathology consistent with this diagnosis is also present in biopsies in El Salvador and Sri Lanka although it is not the only finding on biopsy.

\section{Lead}

The historical outbreak that is most similar to CKDu in terms of mortality occurred in Queensland, Australia residents who survived lead poisoning as children but went on to die of ESRD as adults [14]. Lead paint was used in Queensland from 1890 until it was linked to lead poisoning in children and phased out, starting with a ban in 1922 [14]. Children were exposed through play on painted verandas and railings of raised houses; a type of housing unique to Queensland [14]. As shown in the Fig. 1 below, an epidemiological investigation of mortality from chronic nephritis revealed a dramatic spike in deaths starting in 1905 and peaking in the early 1930s [15].

In autopsy data, the content of lead in skull bone was higher in those who were born in Queensland and died in their third to fifth decade from ESRD of unknown cause with granular contracted kidneys compared to those who died of ESRD from known causes, such as chronic glomerulonephritis, and those who died from non-renal causes $[16,17]$. Furthermore, levels of chelatable lead in urine were also higher in patients with CKD consistent with lead nephropathy [18].

However, in studies of adults who were lead poisoned as children in other geographic areas, increased mortality from ESRD and/or disease severe enough to require dialysis was uncommon. Only persistent partial Fanconi syndrome [19] and a few cases of kidney disease consistent with lead nephropathy have been reported [20,21]. Differences in the extent of exposure may be involved since the Queensland children were not treated with chelation therapy. Researchers in the Queensland outbreak also implicated the additional impact of concentrated urine in children in this warm climate [16].

Higher ESRD mortality or incidence rates have also been reported in lead workers, most of whom were likely very highly exposed $[22,23]$. However, the number of workers with a nonmalignant renal cause of death was still small [24] compared to residents in Queensland and in areas with CKDu. Furthermore, blood lead is easy to measure and elevated levels have not been detected in Sri Lanka [3] or in Central America [25]. Thus, lead exposure is not a likely explanation for $\mathrm{CKDu}$.

\section{Cadmium}

Excessive cadmium exposure has occurred in several areas in Japan but is best known as the cause of Itai-itai ("ouch-ouch") disease in the Jinzu River basin of Toyama prefecture. Ingestion of rice irrigated with industrially polluted water resulted in high level exposure to cadmium. One study reported mean urine cadmium levels of 25.6 and $36.7 \mu \mathrm{g} / \mathrm{g}$ creatinine in 34 males and $38 \mathrm{fe}-$ males, respectively [26]. High levels were also observed in other studies [27]. To put these levels in context, the geometric mean urine cadmium in the U.S. National Health and Nutrition Survey was $0.25 \mu \mathrm{g} / \mathrm{g}$ creatinine in the 2007-2008 survey [28]. The most obvious adverse health effects from the Japanese exposure, reflected in the disease name, were osteomalacia and osteoporosis with secondary fractures and severe pain. Older women were most affected; this is attributed to their poor nutritional status, especially following World War II, since iron deficiency increases cadmium absorption. Proximal 
Table 1 Comparisons of Key Characteristics Among Areas with Reported CKDu

\begin{tabular}{|c|c|c|c|c|}
\hline Risk Factor/Characteristic & Sri Lanka & Central America & India & Egypt \\
\hline \multirow[t]{3}{*}{ Reported Areas } & North Central Province [3] & \multirow{3}{*}{$\begin{array}{l}\text { Most reports from El Salvador and } \\
\text { Nicaragua but appears to extend } \\
\text { across Pacific coast areas of Central } \\
\text { America [37] }\end{array}$} & \multirow{2}{*}{$\begin{array}{l}\text { In state of Andhra Pradesh: coastal in } \\
\text { Uddanam area and } 30-40 \mathrm{~km} \text { inland in } \\
\text { Chimakurthy mandal [52] }\end{array}$} & \multirow[t]{3}{*}{ Reported in El-Minia Governorate } \\
\hline & \multirow{2}{*}{$\begin{array}{l}\text { Present, although to a lesser extent, in } \\
\text { Uva and North Western Provinces [36] }\end{array}$} & & & \\
\hline & & & $\begin{array}{l}\text { In India overall, highest in south which } \\
\text { included Andhra Pradesh [44] }\end{array}$ & \\
\hline Age & $\begin{array}{l}\text { Wide age range; increased prevalence } \\
\text { of eGFR } \leq 60 \mathrm{ml} / \mathrm{min} \text { per } 1.73 \mathrm{~m}^{2} \text { in } \\
\text { fourth and fifth decades [12] }\end{array}$ & Third to fifth decade [37] & $\begin{array}{l}\text { In India overall, younger than patients } \\
\text { with diabetic nephropathy [44] }\end{array}$ & $\begin{array}{l}\text { Mean age of } 46 \text { ( } n=800 \text { patients } \\
\text { on renal replacement therapy) [53] }\end{array}$ \\
\hline Sex & $\begin{array}{l}\text { Female }>\text { male overall but male }> \\
\text { female for CKD stage III -IV [3] }\end{array}$ & Male > female [37] & $\begin{array}{l}\text { Male > female in Uddanam area, [6] and } \\
\text { in India overall [44] }\end{array}$ & Male > female [53] \\
\hline \multirow[t]{3}{*}{ Geographical Characteristics } & Rural [12] & \multirow{2}{*}{$\begin{array}{l}\text { Rural, especially the lowlands along } \\
\text { the Pacific coast [37] }\end{array}$} & \multirow[t]{3}{*}{ Rural - coastal and inland [52] } & \multirow[t]{3}{*}{ Rural [53] } \\
\hline & \multirow{2}{*}{$\begin{array}{l}\text { Dry weather except for two monsoon } \\
\text { periods [36] }\end{array}$} & & & \\
\hline & & $\begin{array}{l}\text { Coastal communities at lower } \\
\text { elevations }(<500 \mathrm{~m})[45]\end{array}$ & & \\
\hline \multirow[t]{3}{*}{ Occupations } & \multirow[t]{3}{*}{$\begin{array}{l}\text { Chena (vegetable and other crops) } \\
\text { farmers; rice farming had a lower risk } \\
\text { compared to chena farming [3] }\end{array}$} & $\begin{array}{l}\text { Risk in coastal agricultural workers } \\
\text { but not in agricultural workers } \\
\text { employed at elevations }>500 \text { m; } \\
\text { sugarcane workers studied in both } \\
\text { locations [45] }\end{array}$ & \multirow[t]{3}{*}{$\begin{array}{l}\text { In Uddanam area, agricultural cultivation } \\
\text { of coconuts, rice, jackfruit and cashews [6] }\end{array}$} & \multirow[t]{3}{*}{ Farming [54] } \\
\hline & & $\begin{array}{l}\text { Compared to coastal agricultural } \\
\text { workers, risk lower in service sector } \\
\text { and agricultural workers at higher } \\
\text { elevations [55] }\end{array}$ & & \\
\hline & & $\begin{array}{l}\text { Intense heat noted in working } \\
\text { conditions in Central America [49] }\end{array}$ & & \\
\hline Socio-economic Status & Low & Low & $\begin{array}{l}\text { In India overall, lower than those with } \\
\text { diabetic nephropathy [44] }\end{array}$ & Not reported \\
\hline \multirow[t]{2}{*}{ Pathology } & $\begin{array}{l}\text { In biopsies from } 211 \text { CKDu patients, the } \\
\text { main pathological features were interstitial } \\
\text { fibrosis, interstitial inflammation and } \\
\text { tubular atrophy of varying degrees [10]. } \\
\text { Authors concluded that interstitial fibrosis } \\
\text { was the earliest detectable pathological } \\
\text { change. }\end{array}$ & $\begin{array}{l}\text { A study of } 57 \text { CKDu patients observed } \\
\text { chronic tubulointerstitial nephropathy } \\
\text { [56]. The authors considered the } \\
\text { glomerular and vascular damage } \\
\text { also observed to be secondary to } \\
\text { the tubulointerstitial damage. }\end{array}$ & \multirow[t]{2}{*}{$\begin{array}{l}\text { Chronic tubulointerstitial nephritis } \\
\text { (no details as reported in abstract from } \\
\text { conference proceedings) [6] }\end{array}$} & \multirow[t]{2}{*}{$\begin{array}{l}\text { Not reported, biopsies rarely } \\
\text { performed [53] }\end{array}$} \\
\hline & $\begin{array}{l}\text { Change. } \\
\text { Interstitial fibrosis and tubular } \\
\text { atrophy, sometimes with nonspecific } \\
\text { interstitial mononuclear cell infiltration, } \\
\text { predominated; glomerular sclerosis, } \\
\text { glomerular collapse, and features of } \\
\text { vascular pathology such as fibrous intimal } \\
\text { thickening and arteriolar hyalinosis } \\
\text { also common }(n=57)[11]\end{array}$ & $\begin{array}{l}\text { A study of } 8 \text { CKDu patients reported } \\
\text { extensive glomerulosclerosis } \\
(29 \%-78 \%) \text { and signs of chronic } \\
\text { glomerular ischemia in combination } \\
\text { with tubular atrophy and interstitial } \\
\text { fibrosis but only mild vascular lesions [9]. } \\
\text { The authors concluded that both } \\
\text { glomerular and tubulointerstitial } \\
\text { compartments were damaged by CKDu. }\end{array}$ & & \\
\hline
\end{tabular}


Table 1 Comparisons of Key Characteristics Among Areas with Reported CKDu (Continued)

\begin{tabular}{|c|c|c|c|c|}
\hline & $\begin{array}{l}\text { Biopsies in } 26 \text { patients (19 in CKD } \\
\text { stages 1-3) reported as consistent } \\
\text { with tubulointerstitial disease; } \\
\text { immunofluorescence tests for } \\
\text { immune-mediated kidney injury } \\
\text { were negative [12] }\end{array}$ & & & \\
\hline Presentation & $\begin{array}{l}\text { Slow progression; minimal } \\
\text { proteinuria (mean } 24 \mathrm{~h} \text { urine } \\
\text { protein }=612.8 \mathrm{mg} \text { in } 109 \\
\text { participants) without active } \\
\text { sediment; bilateral small echogenic } \\
\text { kidneys [12] } \\
\text { Urinary excretion of } \\
\text { alpha-1-microglobulin elevated in } \\
\text { CKDu patients, even in the earliest } \\
\text { CKD stage, compared with } \\
\text { first-generation related controls } \\
\text { residing in the same community } \\
\text { and Japanese controls, suggesting } \\
\text { early renal tubular damage in } \\
\text { CKDu [57] }\end{array}$ & $\begin{array}{l}\text { Minor or no proteinuria or } \\
\text { albuminuria }[6,55] \\
\text { Small echogenic kidneys on } \\
\text { ultrasound [37] } \\
\text { Urinary symptoms, when present, are } \\
\text { positive for pyuria and leukocyte } \\
\text { esterase but urine culture negative [37] }\end{array}$ & $\begin{array}{l}\text { In India overall, advanced CKD, few initial } \\
\text { symptoms, absent or mild hypertension } \\
\text { and little or no proteinuria [44] } \\
\text { In Uddanam area, proteinuria prevalence } \\
\text { of } 20 \% \text { in males and } 12 \% \text { in females [6] }\end{array}$ & Not reported \\
\hline Magnitude & $\begin{array}{l}\text { Age-standardized prevalence } \\
(95 \% \mathrm{Cl}) \text { of albumin-creatinine } \\
\text { ratio } \geq 30 \mathrm{mg} / \mathrm{g} \text { on two separate } \\
\text { tests }[3] \text { : } \\
15.1 \% \text { in Anuradhapura } \\
20.6 \% \text { in Polonnaruwa } \\
22.9 \% \text { in Badulla } \\
16.9 \%(15.5 \%-18.3 \%) \text { in women } \\
12.9 \%(11.5 \%-14.4 \%) \text { in men }\end{array}$ & $\begin{array}{l}\text { Mortality from chronic renal failure } \\
\text { (2007) [58] } \\
\text { El Salvador } \\
\text { Men: } 85.5 / 100,000 \\
\text { Women: 34.1/100,000 } \\
\text { Nicaragua } \\
\text { Men: } 66.2 / 100,000 \\
\text { Women: 22.3/100,000 } \\
\text { USA } \\
\text { Men: } 9.5 / 100,000 \\
\text { Women: 7.0/100/000 } \\
\text { Cuba } \\
\text { Men: } 3.0 / 100,000 \\
\text { Women: } 2.5 / 100,000\end{array}$ & $\begin{array}{l}\text { CKDu is second most common cause of } \\
\text { CKD in India (16.0\%) after diabetic } \\
\text { nephropathy (31.3\%) [44] }\end{array}$ & $\begin{array}{l}\text { Unknown etiology, at } 27 \% \text {, was } \\
\text { leading cause of end-stage renal } \\
\text { disease (ESRD) followed by } \\
\text { hypertension at } 20 \% \text { and } \\
\text { glomerulonephritis at } 11 \% \text { [53] }\end{array}$ \\
\hline
\end{tabular}




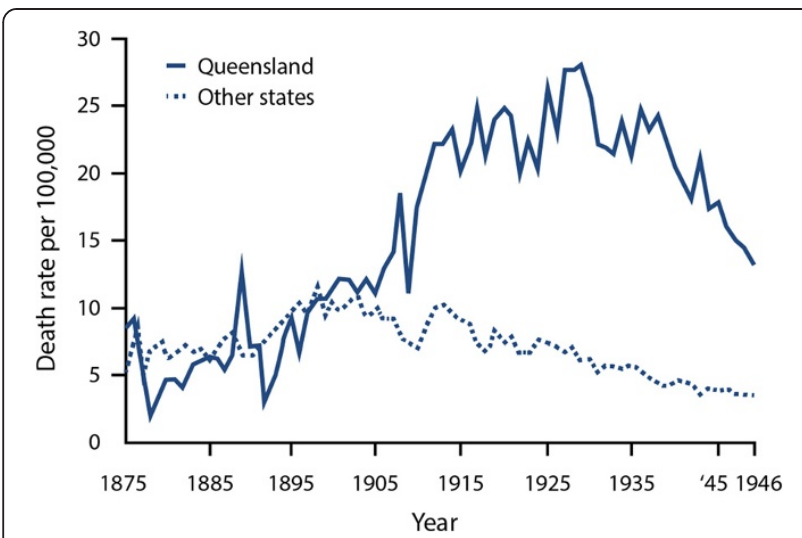

Fig. 1 Annual age specific chronic nephritis mortality rates in persons under forty years of age in Queensland and the other States of Australia. Adapted from Figure 4 from Henderson DA: Chronic nephritis in Queensland. Australas Ann Med 1955, 4(3):163-177. Used with permission from Wiley

tubule damage was also a common feature of this disease and decreased creatinine clearance was reported in affected residents in the Jinzu river basin and other cadmium polluted areas in Japan [26, 29,30]. However, despite high levels of exposure based on cadmium measurement in urine and rice, kidney disease severe enough to result in early death was not commonly reported. Four clinically identified deaths from uremia in Itai-itai patients have been described in the literature [30]. Studies among inhabitants living in the cadmium polluted area of the Kakehashi river basin observed increased mortality from nephritis and nephrosis, also based on small numbers [31].

In a more recent environmental exposure in the Mae Sot district of Thailand, evidence of proximal tubular damage is present but no outbreak of ESRD requiring dialysis or resulting in death has been reported in the affected population with mean urine cadmium levels of $5 \mu \mathrm{g} / \mathrm{g}$ creatinine [32]. A general population study in Belgium reported an association between higher blood lead and lower creatinine clearance; no associations with this outcome were observed with urine or blood cadmium [33]. A similar situation was observed in occupational exposure. Even in exposure conditions considered extremely high by current standards, tubular damage and CKD occurred but were rarely severe enough to progress to ESRD [34, 35].

The recently reported values of 1.04 and $0.65 \mu \mathrm{g} / \mathrm{g}$ creatinine in participants with $\mathrm{CKDu}$ and controls in the Sri Lanka endemic area, respectively, were much lower than in any of the studies described above [3]. Thus, it is unlikely that cadmium is the sole cause of CKDu in Sri Lanka.

\section{Aristolochic acid}

Aristolochic acid, a naturally occurring nephrotoxic compound found in plants of the genus Aristolochiaceae, has been implicated as the cause of interstitial nephritis from ingestion of Chinese herbal medications used for weight loss that were contaminated with this compound [13]. Aristolochic acid has also been implicated in Balkan endemic nephropathy via plants growing around wheat fields in affected areas [13]. CKD from aristolochic acid ingestion does progress to ESRD, within 2-3 years in the case of herb ingestion. However, both aristolochic acid nephropathy and Balkan endemic nephropathy are associated with increased risk for urothelial carcinoma which has not been reported in CKDu to date. Further, data to date, although limited, do not indicate greater exposure to this chemical in the affected areas compared to non-endemic surrounding areas $[36,37]$.

\section{Arsenic}

Elevated standardized mortality rates for kidney disease have been reported in ecologic studies of communities with moderate to high levels of arsenic in their water sources [38]. Reduction in mortality after cessation of exposure in a previously endemic area in Taiwan was also observed [39]. A recent longitudinal study reported an increased risk for incident CKD with baseline urine arsenic concentrations [40]. However, similar to the situation with cadmium, reported arsenic levels in water [3] were much lower in Sri Lanka than in the communities where increased risk was reported in the ecologic studies. Furthermore, mortality in $\mathrm{CKDu}$ is so high that it does not require a mortality study to detect it.

\section{Other environmental causes of kidney disease}

Other exposure-related outbreaks have involved acute kidney injury. Ingestion of formula adulterated with melamine resulted in an outbreak in Chinese infants due to urinary tract obstruction from kidney stones. The long term implications of this exposure remain a research focus [41]. In a much smaller outbreak, diethylene glycol contaminated acetaminophen syrup caused acute kidney injury in Haitian children. The case fatality rate was extremely high (88 of 109 exposed children) [42]. However, the acute nature of these outbreaks is quite different than the pattern described to date in CKDu. Certain medications can also cause or contribute to CKD. Analgesic nephropathy is one of the best known examples of this; also requiring substantial research to make the connection.

\section{CKDu risk factors}

Considering the CKDu characteristics reported globally and the environmental causes of CKD outbreaks identified 
to date, none of the previously established causes alone appears to explain CKDu. Thus, this disease entity is either multifactorial and/or due to a previously unrecognized cause of kidney damage. Two reviews have discussed the range of risk factors under consideration, in Central America [37] and globally [6]. As noted above, different risk factors may be involved in the various locations in which CKDu has been reported. Ethnic diversity may also be a factor. For example, South Asians have an increased risk for coronary artery disease that is not explained by traditional cardiac risk factors [43]. Given the similarities between cardiac and renal risk factors, this risk may be relevant for CKDu in India and Sri Lanka but not necessarily related to $\mathrm{CKDu}$ in Central America. An additional challenge for etiologic determination is that the majority of countries report at least some baseline rate of CKD that appears unrelated to traditional risk factors and thus is considered to be of unknown etiology [2]. As noted by Rajapurkar and colleagues, disease in which the cause could not be determined was the second most common CKD presentation in India and was observed throughout the country [44]. They note that delayed presentation in areas with limited access to healthcare makes establishing a primary diagnosis very challenging. Thus, there is likely some proportion of disease that is due to lack of diagnostic capability within the category of disease not due to any common risk factor that actually represents a novel type of CKDu.

Extreme physical exertion, heat stress, water quality and exposure to agrochemicals are among the potential causes currently being considered for CKDu. The combination of heat stress and physically demanding occupations has received attention in the Central American outbreak based on studies reporting lower rates of $\mathrm{CKDu}$ at higher altitudes in the same agricultural processes [45]. A recent pilot study in Brazilian sugarcane harvesters observed evidence of acute kidney injury over the course of a workday [46] The impact of repeated episodes of heat-induced dehydration has been examined in an animal model to specifically address this cause [47]. Pathology consistent with CKDu, including elevated serum creatinine, proximal tubular injury, and renal inflammation and fibrosis, was observed. Interestingly, this pathology was not observed in fructokinase deficient mice. Fructose containing drinks in combination with heat-induced dehydration was implicated and intervention trials based on the United States' Occupational Safety and Health Administration (OSHA) Heat Illness Prevention Campaign were proposed [48]. In considering this potential etiologic factor, one must consider whether agricultural work has changed within the time frame of the CKDu epidemic. The industrialization of animal husbandry in the form of concentrated animal feeding operations has dramatically changed that field. Has the same magnitude of change occurred for agricultural workers? Work in high levels of ambient heat was common in a recent study of working conditions in Central America [49]. However, in a recent spatial distribution analysis, high temperature did not explain CKDu occurrence after adjustment for area under cultivation for specific crops [50]. Given the increased reliance on agrochemicals in modern agriculture, direct exposure and water contamination remain important considerations as well.

\section{Conclusions and recommendations}

A form of CKD that appears unrelated to traditional risk factors, such as diabetes and hypertension, is responsible for widespread morbidity and mortality in specific geographic locations across three continents. The cause(s) remains unknown; however none of the occupational or environmental exposures that have been implicated in previous outbreaks of nephropathy have been established as sole risk factors in the current outbreaks. Thus, multifactorial or novel risks must be considered. Addressing similarities and differences in $\mathrm{CKDu}$ reported in different geographic areas globally may be of value in unraveling the cause(s) of this severe form of kidney disease.

Future needs include funding for clinical care of affected populations and for continued etiologic research. CKDu mortality is extremely high, reflecting health care limitations in the low income countries impacted by this disease. Therefore, funding for patient care is urgently needed. Funding for preventive medical care to identify kidney disease at earlier, more treatable stages is also necessary. In addition, funding is needed for basic public health measures that are known to be cost effective and also address potential $\mathrm{CKDu}$ risk factors. Examples include water sources that are free of biological and chemical contaminants; work practices that prevent dehydration in workers; and use of accepted safety procedures for agrochemicals. Implementation of these measures will benefit the population overall and may reduce the risk of CKDu since, based on experience with Balkan nephropathy, establishing the etiology may be a prolonged process.

In terms of research funding needs, in addition to continued etiologic studies, communication between research groups in the different geographic areas where $\mathrm{CKDu}$ has been reported would be useful to consider similarities and differences in the disease in each location as well as consolidate research approaches when possible. This would allow development of an internationally accepted definition of CKDu and kidney biopsy pathology criteria. Conference funding would be 
very valuable in this regard. Given the extremely high mortality and morbidity reported with this disease, efforts to identify the cause(s), prevent future cases and provide care for those affected must be a global priority.

\begin{abstract}
Resources for additional information include an issue devoted to CKDu in the MEDICC (Medical Education Cooperation with Cuba) Review: International Journal of Cuban Health and Medicine (http:// www.medicc.org/mediccreview/index.php?issue=28). In addition, reflecting ongoing public concern for this serious disease, news organizations have reported on the outbreaks. The Center for Public Integrity and its International Consortium of Investigative Journalists has several articles and videos such as http://www.publicintegrity.org/ health/mystery-fields. The Central American outbreak and challenges surrounding research related to it are discussed in a recent Science newsfocus [51].
\end{abstract}

\begin{abstract}
Abbreviations
CKDu: Chronic kidney disease of unknown etiology; CKD: Chronic kidney disease; WHO: World Health Organization; NSAIDs: Nonsteroidal anti-inflammatory drugs; ESRD: End-stage renal disease; OSHA: Occupational Safety and Health Administration.
\end{abstract}

\section{Competing interests}

The authors declare that they have no competing interests.

\section{Authors' contributions}

BGJ provided initial concept for this commentary; VMW and JJF made additional contributions to the concept. VMW drafted the manuscript. JJF and BGJ revised the manuscript critically for important intellectual content. All authors read and approved the final manuscript.

\section{Author details}

${ }^{1}$ Department of Environmental Health Sciences, Johns Hopkins University Bloomberg School of Public Health, Baltimore, MD, USA. ²Department of Medicine, Johns Hopkins Medical Institutions, Baltimore, MD, USA. ${ }^{3}$ Welch Center for Prevention, Epidemiology and Clinical Research, Johns Hopkins Medical Institutions, Baltimore, MD, USA. ${ }^{4}$ Department of Pediatrics, Johns Hopkins School of Medicine, Baltimore, MD, USA. ${ }^{5}$ Department of Epidemiology, Johns Hopkins University Bloomberg School of Public Health, Baltimore, MD, USA.

Received: 16 February 2015 Accepted: 15 June 2015

\section{Published online: 19 August 2015}

\section{References}

1. Barsoum RS. Chronic kidney disease in the developing world. N Engl J Med. 2006:354(10):997-9.

2. Jha V, Garcia-Garcia G, Iseki K, Li Z, Naicker S, Plattner B, et al. Chronic kidney disease: global dimension and perspectives. Lancet. 2013;382(9888):260-72.

3. Jayatilake N, Mendis S, Maheepala P, Mehta FR. Chronic kidney disease of uncertain aetiology: prevalence and causative factors in a developing country. BMC Nephrol. 2013;14:180.

4. Jayasumana C, Gajanayake R, Siribaddana S. Importance of Arsenic and pesticides in epidemic chronic kidney disease in Sri Lanka. BMC Nephrol. 2014;15(1):124

5. Redmon JH, Elledge MF, Womack DS, Wickremashinghe R, Wanigasuriya KP, Peiris-John RJ, et al. Additional perspectives on chronic kidney disease of unknown aetiology (CKDu) in Sri Lanka-lessons learned from the WHO CKDu population prevalence study. BMC Nephrol. 2014;15:125.

6. Almaguer M, Herrera R, Orantes CM. Chronic kidney disease of unknown etiology in agricultural communities. MEDICC Rev. 2014;16(2):9-15.

7. Siriwardhana EA, Perera PA, Sivakanesan R, Abeysekara T, Nugegoda DB, Weerakoon KG. Is the staple diet eaten in Medawachchiya, Sri Lanka, a predisposing factor in the development of chronic kidney disease of unknown etiology? - A comparison based on urinary beta2-microglobulin measurements. BMC Nephrol. 2014;15:103.

8. http://www.cao-ombudsman.org/cases/documentlinks/documents/ BU_SummaryReport_August122012.pdf.

9. Wijkstrom J, Leiva R, Elinder CG, Leiva S, Trujillo Z, Trujillo L, et al. Clinical and pathological characterization of Mesoamerican nephropathy: a new kidney disease in Central America. Am J Kidney Dis. 2013;62(5):908-18.

10. Wijetunge S, Ratnatunga NV, Abeysekera DT, Wazil AW, Selvarajah M, Ratnatunga CN. Retrospective analysis of renal histology in asymptomatic patients with probable chronic kidney disease of unknown aetiology in Sri Lanka. Ceylon Med J. 2013;58(4):142-7.

11. Nanayakkara S, Komiya T, Ratnatunga N, Senevirathna ST, Harada KH, Hitomi $\mathrm{T}$, et al. Tubulointerstitial damage as the major pathological lesion in endemic chronic kidney disease among farmers in North Central Province of Sri Lanka. Environ Health Prev Med. 2012;17(3):213-21.

12. Athuraliya NT, Abeysekera TD, Amerasinghe PH, Kumarasiri R, Bandara P, Karunaratne $U$, et al. Uncertain etiologies of proteinuric-chronic kidney disease in rural Sri Lanka. Kidney Int. 2011;80(11):1212-21.

13. De Broe ME. Chinese herbs nephropathy and Balkan endemic nephropathy: toward a single entity, aristolochic acid nephropathy. Kidney Int. 2012;81(6):513-5.

14. Henderson DA. A follow-up of cases of plumbism in children. Australas Ann Med. 1954:3(3):219-24.

15. Henderson DA. Chronic nephritis in Queensland. Australas Ann Med. 1955;4(3):163-77.

16. Inglis JA, Henderson DA, Emmerson BT. The pathology and pathogenesis of chronic lead nephropathy occurring in Queensland. J Pathol. 1978;124(2):65-76

17. Henderson DA, Inglis JA. The lead content of bone in chronic Bright's disease. Australas Ann Med. 1957;6(2):145-54.

18. Emmerson BT. Chronic lead nephropathy: the diagnostic use of calcium EDTA and the association with gout. Australas Ann Med. 1963;12:310-24.

19. Loghman-Adham M. Aminoaciduria and glycosuria following severe childhood lead poisoning. Pediatr Nephrol. 1998;12(3):218-21.

20. Hu H. A 50-year follow-up of childhood plumbism. Hypertension, renal function, and hemoglobin levels among survivors. Am J Dis Child. 1991;145(6):681-7.

21. Moel DI, Sachs HK. Renal function 17 to 23 years after chelation therapy for childhood plumbism. Kidney Int. 1992;42(5):1226-31.

22. Steenland K, Selevan S, Landrigan P. The mortality of lead smelter workers: an update. Am J Public Health. 1992;82(12):1641-4.

23. Chowdhury R, Darrow L, McClellan W, Sarnat S, Steenland K. Incident ESRD among participants in a lead surveillance program. Am J Kidney Dis. 2014:64(1):25-31.

24. Wedeen RP, Malik DK, Batuman V. Detection and treatment of occupational lead nephropathy. Arch Intern Med. 1979;139(1):53-7.

25. McClean MD, Amador J, Laws R, Kaufman J, Weiner D, Rodriguez J, et al Biological Sampling Report: Investigating Biomarkers of Kidney Injury and Chronic Kidney Disease Among Workers in Western Nicaragua. 2012. 2012.

26. Nogawa K, Kobayashi E, Honda R, Ishizaki A, Kawano S, Matsuda H. Renal dysfunctions of inhabitants in a cadmium-polluted area. Environ Res 1980;23(1):13-23.

27. Nogawa K, Kido T. Biological monitoring of cadmium exposure in itai-itai disease epidemiology. Int Arch Occup Environ Health. 1993;65(1 Suppl):S43-6.

28. Centers for Disease Control and Prevention. The Fourth National Report on Human Exposure to Environmental Chemicals, Updated Tables. Atlanta, GA: Department of Health and Human Services; 2012

29. Kido T, Nordberg GF, Roels HA. Cadmium-induced renal effects. In: De Broe ME, Porter GA, Bennett WM, Verpooten GA, editors. Clinical Nephrotoxins: Renal Injury from Drugs and Chemicals. 2nd ed. Dordrecht: Kluwer Academic Publishers; 2003. p. 507-30.

30. Kido T, Nogawa K, Ishizaki M, Honda R, Tsuritani I, Yamada Y, et al. Long-term observation of serum creatinine and arterial blood $\mathrm{pH}$ in persons with cadmium-induced renal dysfunction. Arch Environ Health. 1990:45(1):35-41.

31. Nishijo M, Morikawa Y, Nakagawa H, Tawara K, Miura K, Kido T, et al. Causes of death and renal tubular dysfunction in residents exposed to cadmium in the environment. Occup Environ Med. 2006;63(8):545-50.

32. Honda R, Swaddiwudhipong W, Nishijo M, Mahasakpan P, Teeyakasem W, Ruangyuttikarn W, et al. Cadmium induced renal dysfunction among 
residents of rice farming area downstream from a zinc-mineralized belt in Thailand. Toxicol Lett. 2010;198(1):26-32.

33. Staessen JA, Lauwerys RR, Buchet JP, Bulpitt $C J$, Rondia D, Vanrenterghem $Y$, et al. Impairment of renal function with increasing blood lead concentrations in the general population. The Cadmibel Study Group. N Engl J Med. 1992;327(3):151-6.

34. Adams RG, Harrison JF, Scott P. The development of cadmium-induced proteinuria, impaired renal function, and osteomalacia in alkaline battery workers. Q J Med. 1969;38(152):425-43.

35. Roels HA, Lauwerys RR, Buchet JP, Bernard AM, Vos A, Oversteyns M. Health significance of cadmium induced renal dysfunction: a five year follow up. Br J Ind Med. 1989;46(11):755-64.

36. Wanigasuriya K. Update on uncertain etiology of chronic kidney disease in Sri Lanka's north-central dry zone. MEDICC Rev. 2014;16(2):61-5.

37. Weiner DE, McClean MD, Kaufman JS, Brooks DR. The Central American epidemic of CKD. Clin J Am Soc Nephrol. 2013;8(3):504-11.

38. Zheng L, Kuo CC, Fadrowski J, Agnew J, Weaver VM, Navas-Acien A. Arsenic and Chronic Kidney Disease: A Systematic Review. Curr Environ Health Rep. 2014;1(3):192-207.

39. Chiu HF, Yang CY. Decreasing trend in renal disease mortality after cessation from arsenic exposure in a previous arseniasis-endemic area in southwestern Taiwan. J Toxicol Environ Health A. 2005;68(5):319-27.

40. Zheng LY, Umans JG, Yeh F, Francesconi KA, Goessler W, Silbergeld EK, et al. The association of urine arsenic with prevalent and incident chronic kidney disease: evidence from the strong heart study. Epidemiology. 2015;26(4):601-12.

41. Wang PX, Li HT, Zhang L, Liu JM. The clinical profile and prognosis of Chinese children with melamine-induced kidney disease: a systematic review and meta-analysis. Biomed Res Int. 2013;2013:868202.

42. O'Brien KL, Selanikio JD, Hecdivert C, Placide MF, Louis M, Barr DB, et al. Epidemic of pediatric deaths from acute renal failure caused by diethylene glycol poisoning. Acute Renal Failure Investigation Team. JAMA. 1998;279(15):1175-80.

43. Gupta M, Singh N, Verma S. South Asians and cardiovascular risk: what clinicians should know. Circulation. 2006;113(25):e924-9.

44. Rajapurkar MM, John GT, Kirpalani AL, Abraham G, Agarwal SK, Almeida AF, et al. What do we know about chronic kidney disease in India: first report of the Indian CKD registry. BMC Nephrol. 2012;13:10.

45. Peraza S, Wesseling C, Aragon A, Leiva R, Garcia-Trabanino RA, Torres C, et al. Decreased kidney function among agricultural workers in El Salvador. Am J Kidney Dis. 2012;59(4):531-40.

46. Paula Santos U, Zanetta DM, Terra-Filho M, Burdmann EA. Burnt sugarcane harvesting is associated with acute renal dysfunction. Kidney Int. 2015;87(4):792-9.

47. Roncal Jimenez CA, Ishimoto T, Lanaspa MA, Rivard CJ, Nakagawa T, Ejaz $A A$, et al. Fructokinase activity mediates dehydration-induced renal injury. Kidney Int. 2014;86(2):294-302.

48. Johnson RJ, Glaser J, Sanchez-Lozada LG. Chronic kidney disease of unknown etiology: a disease related to global warming? MEDICC Rev. 2014;16(2):79-80.

49. Benavides FG, Wesseling C, Delclos GL, Felknor S, Pinilla J, Rodrigo F. Working conditions and health in Central America: a survey of 12,024 workers in six countries. Occup Environ Med. 2014;71 (7):459-65.

50. VanDervort DR, Lopez DL, Orantes CM, Rodriguez DS. Spatial distribution of unspecified chronic kidney disease in El Salvador by crop area cultivated and ambient temperature. MEDICC Rev. 2014;16(2):31-8.

51. Cohen J. Mesoamerica's mystery killer. Science. 2014;344(6180):143-7.

52. Reddy DV, Gunasekar A. Chronic kidney disease in two coastal districts of Andhra Pradesh, India: role of drinking water. Environ Geochem Health. 2013;35(4):439-54.

53. El Minshawy O. End-stage renal disease in the El-Minia Governorate, upper Egypt: an epidemiological study. Saudi J Kidney Dis Transpl. 2011;22(5):1048-54.

54. Kamel E, El-Minshawy O. Environmental Factors Incriminated in the Development of End Stage Renal Disease in El-Minia Governorate, Upper Egypt. Int J Nephrol Urol. 2010;2(3):431-7.

55. Torres C, Aragon A, Gonzalez M, Lopez I, Jakobsson K, Elinder CG, et al. Decreased Kidney Function of Unknown Cause in Nicaragua: A Community-Based Survey. Am J Kidney Dis. 2010;55(3):485-96.
56. Lopez-Marin L, Chavez Y, Garcia XA, Flores WM, Garcia YM, Herrera R, et al. Histopathology of chronic kidney disease of unknown etiology in Salvadoran agricultural communities. MEDICC Rev. 2014;16(2):49-54.

57. Nanayakkara S, Senevirathna ST, Karunaratne U, Chandrajith R, Harada KH, Hitomi T, et al. Evidence of tubular damage in the very early stage of chronic kidney disease of uncertain etiology in the North Central Province of Sri Lanka: a cross-sectional study. Environ Health Prev Med. 2012;17(2):109-17.

58. Visualizing renal failure and chronic kidney diseases age-standardized mortality rate in countries of the Americas, 2000-2009 [http://ais.paho.org/phip/viz/ nmh_renalfailure_ckd_visualization.asp]

\section{Submit your next manuscript to BioMed Central and take full advantage of:}

- Convenient online submission

- Thorough peer review

- No space constraints or color figure charges

- Immediate publication on acceptance

- Inclusion in PubMed, CAS, Scopus and Google Scholar

- Research which is freely available for redistribution 